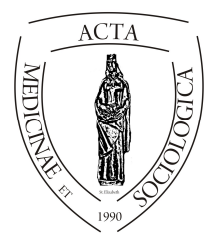

doi:

\title{
Examining the impacts of organizational culture and leadership styles on the organizational performance indicators
}

\section{A szervezeti kultúra és vezetői stílus szervezeti teljesítmény indikátoraira gyakorolt hatása}

Said Abujudeh

PhD student at Károly Ihrig Doctoral School of Management and Business, University of Debrecen, Hungary.

\begin{tabular}{|c|c|}
\hline INFO & ABSTRACT \\
\hline $\begin{array}{l}\text { Said Abujudeh } \\
\text { saidabujudeh@gmail.com }\end{array}$ & \multirow[b]{2}{*}{$\begin{array}{l}\text { Abstract. The objective of this study is to examine the relati- } \\
\text { onship between organizational culture and leadership and } \\
\text { their impacts on such organizational performance indicators, } \\
\text { organizational commitment and job satisfaction, by reviewing } \\
\text { some of the previous organizational culture and leadership li- } \\
\text { terature to clarify the links between both variables and their } \\
\text { impacts on performance indicators. One might assume that a } \\
\text { better organizational culture along with appropriate le- } \\
\text { adership style can lead to a higher level of job satisfaction and } \\
\text { stronger commitment. Accordingly, if an organization has a } \\
\text { strong organizational culture with a suitable leadership style } \\
\text { which is able to keep the organization integration, this will } \\
\text { result in the strengthening of organizational commitment, job } \\
\text { satisfaction, and significant performance enhancement. }\end{array}$} \\
\hline $\begin{array}{l}\text { Keywords } \\
\text { organizational culture, } \\
\text { leadership, organizati- } \\
\text { onal commitment, job sa- } \\
\text { tisfaction, organizational } \\
\text { performance }\end{array}$ & \\
\hline $\begin{array}{l}\text { Kulcsszavak } \\
\text { szervezeti kultúra, veze- } \\
\text { tés, szervezet iránti elkö- } \\
\text { telezettség, munkával } \\
\text { való elégedettség, szerve- } \\
\text { zeti teljesítmény }\end{array}$ & $\begin{array}{l}\text { Absztrakt. A tanulmány célja megvizsgálni a szervezeti kul- } \\
\text { túra és vezetés kapcsolatát, valamint ezek szervezeti teljesít- } \\
\text { ményre - szervezet iránti elkötelezettség, munkával való elé- } \\
\text { gedettség - gyakorolt hatását. Továbbá a korábbi szervezeti } \\
\text { kultúra és vezetés szakirodalma alapján tisztázni a változók } \\
\text { közötti kapcsolatot és ezek teljesítmény mutatókra gyakorolt } \\
\text { hatását. Feltételezhető, hogy egy jobb szervezeti kultúra a } \\
\text { megfelelő vezetői stílussal társulva magasabb szintű elége- } \\
\text { dettséghez és erősebb elkötelezettséghez vezet. Ennek meg- } \\
\text { felelően, amennyiben a szervezet erős szervezeti kultúrával és } \\
\text { alkalmas vezetéssel bír, amely képes megtartani a szervezet }\end{array}$ \\
\hline
\end{tabular}


integrációját, annak az az eredménye,, hogy erősödik a szervezet iránti elkötelezettség és munkával való elégedettség, és a jelentősen nő a teljesítmény.

\section{Introduction}

It is essential for any organization to be adaptable, flexible or changeable against many internal and external influences such as the huge competition in all business sectors, the changes in human resource quality and market demands, the global economy and technological revolutions (Rizescu and Tileaga 2016). These transformation processes received high attention in both academic and applied research due to their significance in maximizing the organizational outcomes (Graham and Nafukho 2007; Nafukho, Graham, and Muyia 2009; Plakhotnik and Rocco 2011). In the core of these processes, the role of the organizational culture and leadership styles becomes essential to sustain the existence of an organization. The organizational culture acts as social glue and reflects the organization identity while leadership plays a valuable role in spreading organizational culture across the organization (Sharma and Sharma 2010).

As long as the organization has a culture which is able to balance the internal integration and external adaptation, it will have a greater competitive advantage compared to other organizations which lack this balance. Therefore, the organization leaders or managers should recognize the importance of ensuring a suitable organizational culture to keep the organization strong enough to attain its mission and survive. To do so, considerable effort should be put into by all organization members at every level. However, each organization has its own organizational culture which has been created over time through interactions among their members and their environment. This has shaped the way their internal and external problems are treated, and has helped them to implement the goals of the organization and to share them as a valid recipe for problem solving, thinking and decision making.

On the one hand, organization's leaders or managers are the key to creating and developing the organizational culture as they are in the position of sensing or detecting the impacts of internal and external changes in their organization early on, and responsible for suggesting and applying the right response to such impacts, and adapting their organizational culture to be able to fit to the new situational environment. On the other hand, the role of the organization's members should also be recognized, as they are participating in organizational culture evolution by their individual values, beliefs, assumptions, and experience.

The organizational culture and leadership style topics are global concerns due to their considerable impacts on the organizational performance (Ogbonna and Harris 2000; Zehir, Gülen, and Zehir 2011) including performance indicators such as organizational commitment and job satisfaction (Al-Sada, Al-Esmael, and Faisal 2017; Lok and John 2004; Silverthorne 2004). Although many studies have been conducted to examine the relations between organizational culture and performance (Ahmed and Shafiq 2014; Chilla, Kibet, and Douglas 2014; Maleka, Kambuwa, and Karodia 2015), and leadership styles and performance (Babalola 2016; Wang, Chich-jen, and 
Mei-ling 2010), few studies have focused on the combined relations of the three concepts (Ogbonna and Harris 2000; Tsai 2011; Zehir et al. 2011), in addition the findings are not always consistent (Cui and $\mathrm{Hu} 2012$ ). Therefore, there is still a need to collect more evidence to describe the relationship between the three concepts. The study aims to clarify the interrelationship between the organizational culture and leadership styles and their impacts on job satisfaction and organizational commitment.

\section{Organizational culture}

The organization is a structure to manage a unit of people designed to achieve certain goals listed by the organization owners. (Boella and van der Torre 2006; Maleka et al. 2015). The culture term is used in the sense of human development which includes ideas, behaviors, experiences, and practices that can be invented, developed, learned and transmitted between individuals and tend to change over time (Creanza, Kolodny, and Feldman 2017). Cultural transmission and change processes occur due to human nature with a need to embrace ideas, beliefs, values, practices, and experiences of other individuals through perception and imitation approach (Henrich and Henrich 2006), followed by screening approach to select the most beneficial culture to be used as a valid lifestyle.

The roots of the organizational culture concept first appeared clearly in anthropogony and social sciences (Detert, Schroeder, and Mauriel 2000). These authors focused their research on finding the key elements that form the organizational culture such as values, ideas, concepts, behavior, opinion, assumptions, ritual, and symbols (Glaser, Zamanou, and Hacker 1987; Sackmann 1991). Accordingly, anthropologists defined culture as a shared set of values, ideas, concepts, and rules of behavior that allow a social group to function and sustain itself together (Hudelson 2004).

According to Wallace, Hunt and Richards (1999), it was not before 1978 that the organizational culture concept was able to find its place in the literature of organization theory, when Peters highlighted the importance of informal dimensions of any organization and referred to them as organizational culture terms. This was followed by the work of Pettigrew (1979) suggesting that organizational culture describes the common meanings which individually and collectively have been accepted to be valid to work for a particular group at a particular time. Pettigrew also explains how groups think, evaluate and behave according to their needs. Their work served as the primary introduction to organizational culture which has become part of organizational psychology studies (Detert et al. 2000).

Despite the fact that there were various definitions of organizational culture concept, most of the definitions agreed in some common features like the organizational culture is learnable and shareable, it is contributes to diverse thinking and the behaviour of groups, and it is acting as a mirror for personal, social and psychological identities (Hofstede et al. 1990). The term of organizational culture refers to the comprehensive picture of shared values, beliefs and the underlying assumptions that are perceived and employed by the members of an organization. Essentially, it is reflecting 
the organization's environment and plays a significant role in holding the organization together (Pool 2000; Schein 1990).

According to Schein (1984:3), the organizational culture is "the pattern of basic assumptions, that a given group has invented, discovered, or developed in learning to cope with its problems of external adaptation and internal integration, and that have worked well enough to be considered valid and, therefore is to be taught to new members as the correct way to perceive, think, and feel in relation to those problems". Thus, at any organization, the culture represents valid rules for interactions within organizations (Yang 2007). The organizational culture is the specific way how the organization is performing its organizational functions, which distinguishes it from other organizations (Hofstede 2011; Khan, Usoro, and Majewski 2012).

Based on the concepts of organizational culture, one of the main factors when creating organizational culture is human action, that is how it is possible to control and adapt it in order to drive the organization to meet its targets. Culture involves systematic rules that show how people should interact together. Thereby, organizations should recognize that they are still actuated and motivated by the shared values and ideas of the people who actually make up the organizations (Kuranchie-Mensah and Amponsah-Tawiah 2016). Furthermore, to operate an organization in a proper way, it is required to define and articulate the suitable organizational culture that can serve the operational needs and help in maximizing organization performance (Matkó and Takács 2017).

The concept of organizational culture is characterized by a high degree of complexity and multidimensional phenomena, which has set a challenge in the process of creating a standard model that is able to describe the various types of organizational culture (Ghinea and Bratianu 2012). This has compelled organizational theorists to present several models and theories by which the various dimensions or levels of any existing organizational culture can be explained. As reported by Chinea and Bratianu (2012), the research of the organizational culture had been conducted in three main directions, as the anthropologist and sociologist researchers were interested to find the key elements forming the organizational culture (Peters 1978; Sackmann 1991). Other organizational theorists went beyond the definitions of the organizational culture, beyond creating models, and tried to analyze the organizational culture itself (Dauber, Fink, and Yolles 2012; Deal and Kennedy 1983; Hofstede et al. 1990; Schein 1984). Meanwhile, other authors were interested in developing models to assess the outcomes of the organizational culture (Cooke and Szumal 2000; Denison and Mishra 1995). Although all the models inspect culture from different aspects, they give a summary of shared principles of knowledge that form organizational culture (Ghinea and Bratianu 2012).

Schein (1984) mentions in his model that organizational culture consists of three different levels of culture in a hierarchical structure. These levels are labeled "artifacts, espoused values, and basic underlying assumptions". The tangible and visible aspects of any organization are reflected in the artifacts level. It is located on the surface and can be easily revealed but it is hard to reflect a complete perspective on the existing culture (Schein 1990). Whereas the invisible and intangible aspects such as the bases, supports and foundations of an organization appear in the underlying assumptions level. It is perceived as an ambiguous level of culture that requires in-depth 
investigations to reveal. The visible aspects influence and are influenced by invisible aspects through rules, regulations and prohibitions which form the espoused values (Hatch 1993; Schein 1990). Dauber et al. (2012) report that the Schein model is not only a well-known model that has received considerable attention in organizational publications, but also one of well-constructed models that applies simplicity and complexity reduction of the organization culture phenomena.

Hatch (1993) introduced a new concept when she presented the dynamic model of culture. Her model is not only an extension of the Schein model by adding a new level called symbols, but she also clarifies the processes that link culture levels. Hatch reformulates the Schein model in a wheel shape. According to Hatch, the culture can be seen by manifestation, realization, symbolization and interpretation processes, and these four processes summarize the interrelation between observable artifacts and invisible assumptions. Hatch argues that when assumptions are manifested and realized, or when they are interpreted and symbolized, they will be transformed into artifacts.

Accordingly, the organizational culture models aim to explain and simplify the complex phenomena, and give a better understanding of culture elements, strength, features, types, and shared values, which contribute to organizational performance, organization integration and survival (Ghinea and Bratianu 2012). Also, shaping and altering the organization's members behaviors and attitudes are explained as the consequences of organizational culture. Additionally, it reveals the dynamic and continuous evolution of the organizational culture where all members are part of the culture. Leadership contribution can be detected in shaping and building the organizational culture either through their actions and behaviors, as the functionalist view sees it, or the organization's members attribute their success to their leadership, as the attribution view sees it (Aydin 2018; Tsui et al. 2006).

\section{Leadership style}

Leadership has often been studied and analyzed, and the characteristics of a good leader, who is capable to lead the group in good or bad situations, have been identified. (AlSawai 2013; George 2000). Leadership can be seen as an influential behaviour and process that are used by leaders to express themselves, and to motivate or change their followers' practices to accomplish shared purposes (Al-Sawai 2013). Leaders, through their leadership competencies, should be ready for making changes, building trust, setting the vision, creating integration, inspiring and motivating their followers (Wallace and Chernatony 2009). As it was identified by Yuki (1989:253) in his valuable review, leadership "includes influencing task objectives and strategies, influencing commitment and compliance in task behaviour to achieve these objectives, influencing group maintenance and identification, and influencing the culture of an organization".

Several models were offered in the literature trying to determine the characteristics of the leadership based on different approaches such as personal traits approach, behavioral, contingency or situational and transformational - transactional approach (Bhatti et al. 2012). The traits approach is based on the common assumption that the natural individual or personal traits alone can determine the leader. Accordingly, leaders are 
born and naturally evolved. Thus, the quality of personal traits can make a difference between effective and ineffective leaders (Macit 2003; Vroom and Jago 2007).

Daft and Lane (2005) reports that the first trial based on behavior approach is the study conducted by Lewin and his colleagues in the early 20th century when they defined two different leadership styles, namely autocratic and democratic. An autocratic leader is a power-centric leader who gains and derives power from the position, who controls rewards and punishments. In contrast, a democratic leader is a power delegator leader, who gains and derives power from the followers' respect and loyalty, who seeks power participation, contributes to followers' satisfaction, and builds trust and loyalty.

Subsequently, behavioral approaches gained considerable attention during the 1950 s and 1960s. Being disenchanted with the search for universal traits of leadership (Vroom and Jago 2007), a series of studies were conducted based on behavioral approach, primarily at Ohio State University and the University of Michigan. These studies focused on how leaders behave or how leaders interact with their followers regardless of leaders' traits (Macit 2003; Vroom and Jago 2007). Regarding contingency approach, it is based on contingency and situational theories which assume that there is no best style that could describe all leaders, but rather the leader's quality is based on situation and task structure (Vroom and Jago 2007). Accordingly, one may find himself propelled in crisis or important events make him show or perform additional leadership qualities. In other words, the contingency situation makes the leader.

Transactional and transformational leadership approaches assume that leaders could employ different styles to lead their followers (Macit 2003). Leaders can establish an exchange process in dealing with followers in terms of rewards and performance, or punishment and mistakes. This reflects the transactional leadership style in which the main concern is to achieve targets and follow the role (Bass, Avolio, and Binghamton 1993). In contrast, transformational leadership is more concerned with adapting the beliefs, values, and needs of followers to serve the organization needs. It mostly focuses on motivation, stimulation, and development of the followers and has direct impacts on organizational culture (Bass et al. 1993; Xenikou and Simosi 2006)

\section{The relationship between organizational culture and leadership}

The backbone of fostering and communicating the organizational culture is the leader who is responsible for simplifying and transforming the complex concept into understandable notions, which can be accepted and performed by the organization members (Tsui et al. 2006).

As it was shown earlier, theorists describe the relationship between leadership and organizational culture by three different views, namely, the functionalist view, attribution view, and contingency view. The functionalist view considers the leaders as the master or draftsman of the changes in organization culture by his simple substantive, visible actions and practices. This role can clearly be seen during establishing an organization when the organization founders outline the organizational culture which 
is based on their own belief, personalities, strategies, visions, and on the various ways of doing things (Denison and Mishra 1995; Schein 1990). Meanwhile, in order to respond to the internal and external adaptation of the organization, the leader is responsible for sustaining and adapting the organizational culture through his behavior, practices, and experience (Ostroff, Kinicki, and Muhammad 2013).

The attribution view assumes that leaders play a symbolic role to serve the organization's choices and results (Meindl, Ehrlich, and Dukerich 1985), and the organization members tend to associate the good or bad result with the leader's practice stemming from the high level of power and control the leaders have (Sarros, Cooper, and Santora 2008; Tsui et al. 2006). The attribution view seems to be concerted with the anthropological view which argues that leaders alone do not create culture, but as a matter of fact they are part of the generated culture (Smircich 1983). The contingency view suggests that leaders' importance can clearly be seen in contingency situations such as crises, conflicts and problems that an organization may face at any time or any place (House, Spangler, and Woycke 1991).

Similarly, as Ogbonna and Harris report, (2000), once an organization has built a strong organizational culture, it will be hard to change or modify it. Therefore it would be more efficient to develop or alter the existing leadership style instead of changing culture if the organization . However, strong evidence supports the functionalist view, in which leaders have the power to shape and evolve the organizational culture (Sarros et al. 2008). Thus, leaders have the opportunity to shape or adopt a set of behaviors which can be observed and learned as a valid way of thinking and problem-solving, and by doing so the existing organizational culture can evolve (Pfeifer, Schmitt, and Voigt 2005).

\section{Organizational performance indicators}

The organizational performance concept refers to the ability of an organization to utilize its available resources efficiently and to perform its activity so that they can ensure sustainable accomplishments which is consistent with the organization objectives (Jenatabadi 2015). Due to its multidimensional nature, the organizational performance term has gained considerable attention both in academic and practical studies (Ogbonna and Harris 2000).

The association between leadership and organizational culture is firmly established in the organizational literature owing to the significant impacts of both variables on organizational performance. Many studies were conducted to examine this relationship concentrating on financial indicators (Ogbonna and Harris 2000), and nonfinancial indicators (social and/or employee attitudes indicators ), which were mostly in connection with job performance, organizational commitment and job satisfaction (Lok and John 2004; Wang et al. 2010).

The assumption that organizational performance is highly dependent on the leaders, organizational culture and the attitudes of organization's members has absolutely been confirmed in the organizational literature (Matkó and Takács 2017; Tsui et al. 2006). 
Despite the fact that the relationships between leadership style and performance, organizational culture and performance have gained considerable attention in many types of research, which were conducted independently from one another, only a few studies have focused on the association between the three variables. In addition, just a few of them have been able to reveal that relationship. (Ogbonna and Harris 2000).

Ogbonna and Harris (2000) investigate the association among leadership style, organizational culture, and performance using some financial indicators like market share and sales growth Their finding provides a strong insight into the role of organizational culture in mediating the relationship between leadership and performance. Their finding is consistent with the study conducted by Xenikoi and Simosi (2006), in which they examine the association between transformational leadership and performance. They also include organizational culture as a further variable. Three culture orientations were used, namely humanistic, achievement, and adaptive orientations. The study concludes that the transformational leadership and humanistic orientation culture are indirectly associated with business performance through achievement orientation culture, in addition, achievement and adaptive cultural orientations have a direct effect on organization's performance.

Moreover the relationship between organizational performance indicators like job satisfaction, organizational commitment, job performance, and organizational culture has gained considerable attention owing to the assumption that the attitude of organization's members is a key element in sustaining high organizational performance (Gregory et al. 2009). However, Patterson et al. (1997) suggest that there is a positive association between employee attitude, organizational culture, human resources management, and company performance, and they also state that employee satisfaction and commitment are important to enhance organizational performance.

\section{The role of job satisfaction}

According to Yousef (2002), job satisfaction is defined as a collection of feelings that an individual holds towards his or her job. Job satisfaction as an emotional factor is an important indicator of determining organizational performance and might be seen as a mirror of organizational culture and leadership style. Tsai (2011) was interested in examining the relationship between leadership style, organizational culture and job satisfaction as a predictor of high performance. The results show that leadership and organizational culture are significantly correlated and both are directly associated with job satisfaction.

The literature presents empirical evidence showing that a high level of job satisfaction is significantly correlated with the employee's overall motivation for their work which is an important parameter of maximizing individual performance (Tietjen and Myers 1998). Consequently, one might assume that a higher level of job satisfaction could increase employee productivity and organizational commitment. This assumption has been tested empirically in many previous studies (Gregory et al. 2009; Srivastava 2013; Tsui et al. 2006). Similarly, a low level of employee satisfaction may lead to the migration of members from one organization to another, which usually reduces the level of sustainable performance of the abandoned organization (Barmby, 
Bryson, and Eberth 2012). Thus, all organizations must recognize the impact of employee satisfaction on performance, and also how it can lead to significant loss in the advantages of accumulated human resources over time.

According to Danchev and Sevinc (2012), the level of job satisfaction is firstly affected by the financial level of the employee, as well as its related aspects. If these aspects increase, the level of job satisfaction will increase, too. Secondly, the nonfinancial aspects such as organizational culture, leadership style, motivation, work stress and human resource management practice may positively or negatively influence the job satisfaction level. Hamermesh (1999) declares that "only one measure, the satisfaction that workers derive from their jobs, might be viewed as reflecting how they react to the entire changing panoply of job characteristics". And based on the existing level of job satisfaction, the employee will be more or less likely to contribute to or support organizational performance.

\section{The role of organizational commitment}

The organizational commitment determines the relationship between the organization and its members. Porter et al. (1974:604) define organizational commitment as "the strength of an individual's identification with and involvement in a particular organization". They classify three basic behaviors that an individual might employ to show his commitment towards his organization: the strong belief in or acceptance of the organization's values and goals; the desire to make a great effort on behalf of the organization; and the continued intention to retain membership in the organization.

The role of organizational commitment in enhancing the organizational performance is firmly agreed among the organizational theoreticians, due to its significant impacts on improving the organizational performance (Keller 1997; Tao et al. 1998). It can be seen as an antecedent of organizational outcomes like job satisfaction (Yousef 2000), performance, motivation, turnover, attendance and absenteeism (Mowday, Steers, and Porter 1979).

Several studies were conducted to examine the factors that influence the organizational commitment such as organizational culture (Mitić et al. 2016; Silverthorne 2004), leadership style (Babalola 2016), and others were interested to study the combined relationship of both variables with organizational commitment (Al-Sada et al. 2017; Lok and John 2004), or organizational climate and supervisory behavior (Tao et al. 1998). Meanwhile, Bakan et al. (2011), stress on the organizational commitment importance for the organizational overall success, in which an organization does not only depend on how to create or improve the organization's members competences, but also on how it is possible to increase their commitment towards their organization.

Mitić et al. (2016) were interested in examining the impacts of particular dimensions of organizational culture in three organizational commitment dimensions: organizational identification, organizational involvement and organizational loyalty on the basis of a sample of Serbian companies. Their findings reveal that all organizational culture dimensions have a significant correlation with organizational commitment. While the most affected dimension of organizational commitment is organizational identification, this dimension expresses a strong sense of being proud to belong to the organization. 
Yousef (2000) proves that leadership styles influence organizational commitment, job satisfaction and performance, and also suggests that those who realize their leaders employ consultative or participative leadership style manifest a high level of commitment toward their organizations, have a high level of job satisfaction and performance. Lok and John (2004) examine the organizational culture and leadership style focusing on the organizational commitment and job satisfaction among a sample from two countries. Bureaucratic, innovative, and supportive cultures were chosen to assess the organizational culture. In order to measure the leadership style, consideration and initiating structures were used, and the authors conclude that job satisfaction and organizational commitment are positively affected by innovative and supportive cultures and a considerate leadership style.

\section{Summary}

The findings of this review highlight the significant role of the organizational culture and leadership to increase the level of such organizational outcomes as job satisfaction, commitment, and performance. Therefore, all organizations should recognize and assess the impacts of their organizational culture and leadership styles on their organizational performance, based on the previous results which were conducted from different perspectives, the organizational culture and leadership seem to influence the level of job satisfaction and organizational commitment. Thus, both are important elements for an organization to sustain and improve its performance.

Based on this article, it seems obvious that an organization with an organizational culture that meets with an appropriate leadership style can easily establish a successful and sustainable organizational outcome. Furthermore, both the organizational culture and leadership styles support the commitment of organization's members towards their organization. This way, the members feel bonded with their organization and work hard to reach the drawn goals. One might assume that a better organizational culture along with appropriate leadership styles may lead to a higher level of job satisfaction and strengthen organizational commitment, therefore it will lead to significant performance enhancement. In order to support this assumption empirically, a study will be conducted in the future.

\section{Reference}

1. Ahmed, M., \& Shafiq, S. (2014). The Impact of Organizational Culture on Organizational Performance : Global Journal of Management and Business Research: A Administration and Management, 14(3), 21-29.

2. Al-Sada, M., Al-Esmael, B., \& Faisal, M. N. (2017). Influence of organizational culture and leadership style on employee satisfaction, commitment and motivation in the educational sector in Qatar. EuroMed Journal of Business, 12(2), 163-188. DOI: https://doi.org/10.1108/emjb-02-2016-0003

3. Al-Sawai, A. (2013). Leadership of healthcare professionals: where do we stand? 
Oman Medical Journal, 28(4), 285-287.

DOI: https://doi.org/10.5001/omj.2013.79

4. Aydin, B. (2018). The role of organizational culture on leadership styles. Manas Journal of Social Studies, 7(1), 267-279.

5. Babalola, S. S. (2016). The Effect Of Leadership Style, Job Satisfaction And Employee-Supervisor Relationship On Job Performance And Organizational Commitment. The Journal of Applied Business Research, 32(3), 935-946. DOI: https://doi.org/10.19030/jabr.v32i3.9667

6. Bakan, İ., Büyükbeşe, T., \& Erşahan, B. (2011). An Investigation of Organizational Commitment and Education Level among Employees. International Journal of Emerging Sciences, 1(3), 231-245.

7. Barmby, T., Bryson, A., \& Eberth, B. (2012). Human Capital, Matching and Job Satisfaction. National Institute of Economic and Social Research, (390), 1-8.

8. Bass, B. M., Avolio, B. J., \& Binghamton, S.-. (1993). Transformational Leadership and Organizational Culture. Public Administration Quarterly, 17(1), 112-121.

9. Bhatti, N., Maitlo, G. M., Shaikh, N., Hashmi, M. A., \& Shaikh, F. M. (2012). The Impact of Autocratic and Democratic Leadership Style on Job Satisfaction. International Business Research, 5(2), 192-201.

DOI: https://doi.org/10.5539/ibr.v5n2p192

10. Boella, G., \& van der Torre, L. (2006). Coordination and Organization Definitions, Examples and Future Research Directions. Electronic Notes in Theoretical Computer Science, 150(3), 3-20.

DOI: https://doi.org/10.1016/j.entcs.2006.03.002

11. Chilla, H. A., Kibet, Y., \& Douglas, M. (2014). Effects Of Organizational Culture On Organizational Performance In The Hospitality Industry. International Journal of Business and Management Invention, 3(1), 1-13.

12. Cooke, R. A., \& Szumal, J. L. (2000). Using the organizational culture inventory to understand the operating cultures of organizations. In N. M. Ashkanasy, C. P. M. Wilderom, \& M. F. Peterson (Eds.), Handbook of organizational culture and climate, 147-162 Thousand Oaks, CA: Sage.

13. Creanza, N., Kolodny, O., \& Feldman, M. W. (2017). Cultural evolutionary theory: How culture evolves and why it matters. Proceedings of the National Academy of Sciences, 114(30), 7782-7789.

DOI: https://doi.org/10.1073/pnas.1620732114

14. Cui, X., \& Hu, J. (2012). A Literature Review on Organization Culture and Corporate Performance. International Journal of Business Administration, 3(2), 28 37. DOI: https://doi.org/10.5430/ijba.v3n2p28

15. Daft, R. L., \& Lane, P. G. (2005). The Leadership Experience (4th ed.). Mason, $\mathrm{OH}$ : South-Western.: Thomson.

16. Danchev, A., \& Sevinc, E. (2012). Willingness to Work, Human Capital and Job Satisfaction: A Case Study for Turkey. Eurasian Journal of Business and Economics, 5(10), 71-90.

17. Dauber, D., Fink, G., \& Yolles, M. (2012). A Configuration Model of Organizational Culture. SAGE Open, 2(1), 1-16.

DOI: https://doi.org/10.1177/2158244012441482 
18. Deal, T. E., \& Kennedy, A. A. (1983). Culture: A New Look Through Old Lenses. The Journal of Applied Behavioral Science, 19(4), 498-505. DOI: https://doi.org/10.1177/002188638301900411

19. Denison, D. R., \& Mishra, A. K. (1995). Toward a Theory of Organizational Culture and Effectiveness. Organization Science, 6(2), 204-223. Retrieved from http://www.jstor.org/stable/2635122

20. Detert, J. R., Schroeder, R. G., \& Mauriel, J. J. (2000). A framework for linking culture and improvement initiatives in organizations. Academy of Management Review, 25(4), 850-863. DOI: https://doi.org/10.5465/amr.2000.3707740

21. George, J. M. (2000). Emotions and Leadership: The Role of Emotional Intelligence. Human Relations, 53(8), 1027-1055.

DOI: https://doi.org/10.1177/0018726700538001

22. Ghinea, V. M., \& Bratianu, C. (2012). Organizational Culture Modeling. Management \& Marketing Challenges for the Knowledge Society, 7(2), 257-276.

23. Glaser, S. R., Zamanou, S., \& Hacker, K. (1987). Measuring and interpreting organizational culture. Management Communication Quarterly, 1(2), 173-198. DOI: https://doi.org/10.1177/0893318987001002003

24. Graham, C. M., \& Nafukho, F. M. (2007). Culture, organizational learning and selected employee background variables in small-size business enterprises. Journal of European Industrial Training, 31(2), 127-144.

DOI: https://doi.org/10.1108/03090590710734354

25. Gregory, B. T., Harris, S. G., Armenakis, A. A., \& Shook, C. L. (2009). Organizational culture and effectiveness: A study of values, attitudes, and organizational outcomes. Journal of Business Research, 62, (7), 673-679, 62(7), 673-679. DOI: https://doi.org/10.1016/j.jbusres.2008.05.021

26. Hamermesh, D. S. (1999). The Changing Distribution Of Job Satisfaction. National Bureau of Economic Research, Working Paper No. 7332. Retrieved from http://www.nber.org/papers/w7332

27. Hatch, M. J. (1993). The Dynamics of Organizational Culture. The Academy of Management Review, 18(4), 657-693. DOI: https://doi.org/10.2307/258594

28. Henrich, J., \& Henrich, N. (2006). Culture, evolution and the puzzle of human cooperation. Cognitive Systems Research, 7(2-3), 220-245. DOI: DOI: https://doi.org/10.1016/j.cogsys.2005.11.010

29. Hofstede, G. (2011). Dimensionalizing Cultures: The Hofstede Model in Context. Online Readings in Psychology and Culture, 2(1), 1-26. DOI: DOI: https://doi.org/10.9707/2307-0919.1014

30. Hofstede, G., Neuijen, B., Ohayv, D. D., \& Sanders, G. (1990). Measuring Organizational Cultures: A Qualitative and Quantitative Study Across Twenty Cases. Administrative Science Quarterly, 35(2), 286-316.

DOI: https://doi.org/10.2307/2393392

31. House, R. J., Spangler, W. D., \& Woycke, J. (1991). Personality and charisma in the U.S. presidency: A psychological theory of leader effectiveness. Administrative Science Quarterly, 36(3), 364-396. DOI: https://doi.org/10.2307/2393201

32. Hudelson, P. M. (2004). Culture and quality: An anthropological perspective. International Journal for Quality in Health Care, 16(5), 345-346. DOI: https://doi.org/10.1093/intqhc/mzh076 
33. Jenatabadi, H. S. (2015). An Overview of Organizational Performance Index : Definitions and Measurements. In Researchgate, viewed 26 january 2019 (pp. 110). DOI: https://doi.org/10.13140/RG.2.1.4298.3849

34. Keller, R. T. (1997). Job involvement and organizational commitment as longitudinal predictors of job performance: A study of scientists and engineers. Journal of Applied Psychology, 82(4), 539-545. DOI: https://doi.org/10.1037/00219010.82.4.539

35. Khan, I. U., Usoro, A., \& Majewski, G. (2012). An organisational culture model for comparative studies and assessment of IT projects. International Journal of Human Capital and Information Technology Professionals, 3(2), 63-83. DOI: https://doi.org/doi:10.4018/jhcitp.2012040105

36. Kuranchie-Mensah, E., \& Amponsah-Tawiah, K. (2016). Employee Motivation and Work Performance: A Comparative Study of Mining Companies in Ghana. Journal of Industrial Engineering and Management, 9(2), 255-309. DOI: https://doi.org/10.3926/jiem.1530

37. Lok, P., \& John, C. (2004). The effect of organisational culture and leadership style on job satisfaction and organisational commitment A cross-national comparison. Journal of Management Development, 23(4), 321-338. DOI: https://doi.org/10.1108/02621710410529785

38. Macit, M. (2003). Leadership and Bass Transactional and Transformational leadership Theory. Selçuk Üniversitesi İktisadi ve İdari Bilimler Fakültesi Sosyal ve Ekonomik Araştırmalar Dergisi, Yıl, 1, 87-114.

39. Maleka, N. K., Kambuwa, M., \& Karodia, A. M. (2015). Assissing Organizational Culture Management And Its Impact On Performance At SEW Eurodrive ( SA ). Arabian Journal of Business and Management Review, 3(3), 1-27. DOI: https://doi.org/10.12816/0014505

40. Matkó, A., \& Takács, T. (2017). Examination of the relationship between organizational culture and performance. International Review of Applied Sciences and Engineering, 8(1), 99-105. DOI: https://doi.org/10.1556/1848.2017.8.1.14

41. Meindl, J. R., Ehrlich, S. B., \& Dukerich, J. M. (1985). The Romance of Leadership. Administrative Science Quarterly, 30(1), 78-102. DOI: https://doi.org/10.2307/2392813

42. Mitić, S., Vukonjanski, J., Terek, E., Gligorović, B., \& Zorić, K. (2016). Organizational culture and organizational commitment: Serbian case. Jornal of Engineering Managment and Competitiveness, 7(1), 21-27.

DOI: https://doi.org/10.5937/jemc1601021m

43. Mowday, R. T., Steers, R. M., \& Porter, L. W. (1979). The measurement of organizational commitment'. Journal of Vocational Behavior, 14(2, pp. 224-47), 224-247. DOI: https://doi.org/10.1016/0001-8791(79)90072-1

44. Nafukho, F. M., Graham, C. M., \& Muyia, M. H. (2009). Determining the relationship among organizational learning dimensions of a small-size business enterprise. Journal of European Industrial Training, 33(1), 32-51.

DOI: https://doi.org/10.1108/03090590910924360

45. Ogbonna, E., \& Harris, L. C. (2000). Leadership style, organizational culture and performance: empirical evidence from UK companies. International Journal of Human Resource Management, 11(4), 766-788. 
DOI: https://doi.org/10.1080/09585190050075114

46. Ostroff, C., Kinicki, A. J., \& Muhammad, R. S. (2013). Organizational Culture and Climate. In I. B. Weiner (Ed.), handbook of Psychology (2nd ed., pp. 643676). John Wiley \& Sons, Inc.

DOI: https://doi.org/10.1002/9781118133880.hop212024

47. Patterson, M. G., West, M. A., Lawthom, R., \& Nickell, S. (1997). Impact of People Management Practices on Business Performance. Issues in People Management. London: Institute of Personnel and Development, The Cromwell Press, Wiltshire.

48. Peters, T. J. (1978). Symbols, patterns, and settings: An optimistic case for getting things done. Organizational Dynamics, 7(2), 3-23.

DOI: https://doi.org/10.1016/0090-2616(78)90035-9

49. Pettigrew, A. M. (1979). On Studying Organizational Cultures. Administrative Science Quarterly, 24(4), 570. DOI: https://doi.org/10.2307/2392363

50. Pfeifer, T., Schmitt, R., \& Voigt, T. (2005). Managing change: quality-oriented design of strategic change processes. The TQM Magazine, 17(4), 297-308. DOI: https://doi.org/10.1108/09544780510603152

51. Plakhotnik, M. S., \& Rocco, T. S. (2011). What Do We Know, How Much, and Why It Matters: Organizational Culture and AHRD Research 1994-2009. Human Resource Development Review, 10(1), 74-100.

DOI: https://doi.org/10.1177/1534484310388992

52. Pool, S. W. (2000). Organizational culture and its relationship between job tension in measuring outcomes among business executives. Journal of Management Development, 19(1), 32-49.

DOI: https://doi.org/http://dx.doi.org/10.1108/02621710010308144

53. Porter, L. W., Steers, R. M., Mowday, R. T., \& BOULIAN, P. V. (1974). Organizational Commitment, Job Satisfaction, and Turnover among Ppsychiatric Technician. Journal of Applied Psychology, 59(5), 603-609.

DOI: https://doi.org/10.1037/h0037335

54. Rizescu, A., \& Tileaga, C. (2016). Factor influencing continuous organisational change. Journal of Defense Resources Management, 7(2), 139-144.

55. Sackmann, S. A. (1991). Uncovering Culture in Organizations. The Journal of Applied Behavioral Science, 27(3), 295-317.

DOI: https://doi.org/10.1177/0021886391273005

56. Sarros, J. C., Cooper, B. K., \& Santora, J. C. (2008). Building a Climate for Innovation Through Transformational Leadership and Organizational Culture. Journal of Leadership \& Organizational Studies, 15(2), 145-158.

DOI: https://doi.org/10.1177/1548051808324100

57. Schein, E. H. (1984). Coming to a new awareness of organizational culture. Sloan Management Review, 25(2), 3-16. Retrieved from https://sloanreview.mit.edu/article/coming-to-a-new-awareness-of-organizational-culture/

58. Schein, E. H. (1990). Organizational Culture. American Psychologist, 45(2), 109-119. Retrieved from DOI: http://dx.doi.org/10.1037/0003-066X.45.2.109

59. Sharma, S. K., \& Sharma, A. (2010). Examining the Relationship between Organisational Culture and Leadership Styles. Journal of the Indian Academy of Applied Psychology, 36(1), 97-105. 
60. Silverthorne, C. (2004). The impact of organizational culture and person-organization fit on organizational commitment and job satisfaction in Taiwan. Leadership \& Organization Development Journal, 25(7), 592-599.

DOI: https://doi.org/10.1108/01437730410561477

61. Smircich, L. (1983). Concepts of Culture and Organizational Analysis. Administrative Science Quarterly, 28(3), 339-358. DOI: https://doi.org/10.2307/2392246

62. Srivastava, S. (2013). Job Satisfaction and Organizational Commitment Relationship: Effect of Personality Variables. Vision, 17(2), 159-167.

DOI: https://doi.org/10.1177/0972262912483529

63. Tao, M., Takagi, H., Ishida, M., \& Masuda, K. (1998). A study of antecedents of organizational commitment. Japanese Psychological Research, 40(4), 198-205.

64. Tietjen, M. A., \& Myers, R. M. (1998). Motivation and job satisfaction. Management Decision, 36(4), 226-231.

DOI: https://doi.org/10.1108/00251749810211027

65. Tsai, Y. (2011). Relationship between Organizational Culture, Leadership Behavior and Job Satisfaction. BMC Health Services Research, 11(1), 98.

DOI: https://doi.org/10.1186/1472-6963-11-98

66. Tsui, A. S., Zhang, Z., Wang, H., Xin, K. R., \& Wu, J. B. (2006). Unpacking the relationship between CEO leadership behavior and organizational culture. The Leadership Quarterly, 17, 113-137.

DOI: https://doi.org/10.1016/j.leaqua.2005.12.001

67. Vroom, V. H., \& Jago, A. G. (2007). The Role of the Situation in Leadership. American Psychologist, 62(1), 17-24.

DOI: https://doi.org/10.1037/0003-066X.62.1.17

68. Wallace, E., \& Chernatony, L. De. (2009). Service Employee Performance: Its Components and Antecedents. Journal of Relationship Marketing, 8(2), 82-102. DOI: https://doi.org/10.1080/15332660902876612

69. Wallace, J., Hunt, J., \& Richards, C. (1999). The relationship between organisational culture, organisational climate and managerial values. International Journal of Public Sector Management, 12(7), 548-564.

DOI: https://doi.org/10.1108/09513559910305339

70. Wang, F., Chich-jen, S., \& Mei-ling, T. (2010). Effect of leadership style on organizational performance as viewed from human resource management strategy. African Journal of Business Management, 4(18), 3924-3936.

71. Xenikou, A., \& Simosi, M. (2006). Organizational culture and transformational leadership as predictors of business unit performance. Journal of Managerial Psychology, 21(6), 566-579. DOI: https://doi.org/10.1108/02683940610684409

72. Yang, J. Te. (2007). Knowledge sharing: investigating appropriate leadership roles and collaborative culture. Tourism Management -Elistivar, 28(2), 530-543. DOI: https://doi.org/10.1016/j.tourman.2006.08.006

73. Yousef, D. A. (2000). Organizational commitment: A mediator of the relationships of leadership behavior with job satisfaction and performance in a nonwestern country. Journal of Managerial Psychology, 15(1), 6-24.

DOI: https://doi.org/10.1108/02683940010305270

74. Yousef, D. A. (2002). Job satisfaction as a mediator of the relationship between role stressors and organizational commitment A study from an Arabic cultural. 
Journal of Managerial Psychology, 17. 4, 250-266.

DOI: https://doi.org/10.1108/02683940210428074

75. Yukl, G. (1989). Managerial Leadership : A Review of Theory and Research. Journal of Management, 15(2), 251-289.

DOI: https://doi.org/10.1177/014920638901500207

76. Zehir, C., Gülen, Ö., \& Zehir, S. (2011). The Effects of Leadership Styles and Organizational Culture over Firm Performance: Multi-National Companies in Istanbul. Procedia - Social and Behavioral Sciences, 24, 1460-1474.

DOI: https://doi.org/10.1016/j.sbspro.2011.09.032 